\title{
Recrudescence Induced by Cyclophosphamide of Chronic Trypanosoma cruzi Infection in Mice is Influenced by the Parasite Strain
}

\author{
Maria Elizabeth S Pereira, Luis Mauro T Santos, Márcio Sobreira S Araújo, \\ Zigman Brener
}

Centro de Pesquisas René Rachou-FIOCRUZ, Caixa Postal 1743, 30190-002 Belo Horizonte, MG, Brasil

Reactivation of chronic chagasic patients may occur upon use of immunosuppressive drugs related to kidney or heart transplantation or when they are affected by concomitant HIV infection. This recrudescence, however, does not occur in all chagasic patients exposed to immunosuppressive agents. We therefore investigated the influence of Trypanosoma cruzi strains in the recrudescence of the parasitism in mice at the chronic phase treated with cyclophosphamide, an immunosuppressor that blocks lymphocytes DNA synthesis and therefore controls B cells response. A large variation was detected in the percentages of newly established acute phases in the groups of mice inoculated with the different strains. We suggest that reactivation of chronic $\mathrm{T}$. cruzi infections is influenced by the parasite intrinsic characteristics, a phenomenon that might occur in the human disease.

Key words: Trypanosoma cruzi - strains - immunosuppression - cyclophosphamide

Trypanosoma cruzi infection in humans is characterized by an acute phase with patent parasitemia which lasts one to two months followed by a lifelong chronic phase with subpatent parasitemia and scarce tissue parasites. Recrudescence of the parasitism in the chronic phase may occur upon administration of immunosuppressive agents. Thus chronic chagasic patients submitted to heart or kidney transplantation treated with immunosuppressor drugs are liable to present reactivation of the T. cruzi infection (Stolf et al. 1987). Acquired immunodeficiency syndrome (AIDS) is also an important hazard for chronic chagasic patients and an increasing number of patients with concomitant HIV and Chagas disease display new acute phase infection characterized by $T$. cruzi meningoencephalitis, myocarditis and patent parasitemia (Rocha et al. 1994).

Interesting, this iatrogenic renewal of the acute phase does not occur in all chronic chagasic patients exposed to immunosuppressive agents. Barousse et al. (1980) carried out complete autopsies of six chronic chagasic patients who received immunosuppressive drugs such as prednisone and cyclophosphamide $(\mathrm{Cy})$ for treatment of concurrent diseases but no evidence of reactivated parasitism was detected. Lopez Blanco et al. (1992) reported that nine chronic chagasic patients recipients of transplanted kidneys and submitted to immunosuppressive drugs have not also shown evidence of parasitism during prolonged follow-up.

Received 23 March 1995

Accepted 18 September 1995
Since the course of experimental Chagas disease is strongly influenced by $T$. cruzi strains and responses of the host immunity (Krettli \& Brener 1976), we decided to investigate the phenomenon of recrudescence in groups of mice chronically infected with eight different strains treated with $\mathrm{Cy}$, an immunosuppressor of the humoral response. Distinct patterns of parasitemia emerged from the experiments, suggesting that the model herein described may contribute to a better knowledge of immunosuppression in the human disease.

\section{MATERIALS AND METHODS}

T. cruzi strains and mice inoculation - Table I identifies the eight strains, their origin and provides information on the inocula as well as the number of days of infection of the mice used in the experiments. Female albino Swiss mice, 18$20 \mathrm{~g}$, were inoculated by intraperitoneal route with either T. cruzi bloodstream forms (BTry) or metacyclic trypomastigotes (MTry) obtained by cultivating in Liver Infusion-Tryptose (LIT) medium parasites recently isolated by hemoculture from infected mice. Each strain was inoculated in 30 mice and then 20 were treated with $\mathrm{Cy}$ and 10 kept for control. The mice inoculated with the different strains were kept in the laboratory for six to eight months. Before Cy administration the persistence of ongoing T. cruzi infection was confirmed by hemocultures carried out by inoculating $0.2-0.4 \mathrm{ml}$ of blood collected from mice orbital venous sinus into two tubes containing $5 \mathrm{ml}$ of LIT medium that were incubated at $26-28^{\circ} \mathrm{C}$ and examined microscopically for living flagellates after 30-60 days. The number of BTry in the 
TABLE I

Trypanosoma cruzi strains used in immunosuppression experiments

\begin{tabular}{|c|c|c|c|}
\hline $\begin{array}{l}\text { T. cruzi } \\
\text { strains }\end{array}$ & Origin & Inoculum & $\begin{array}{l}\text { Days of } \\
\text { infection }\end{array}$ \\
\hline CL & $\begin{array}{c}\text { Triatoma infestans from R.G. Sul, Brazil } \\
\text { (Brener \& Chiari 1963) }\end{array}$ & 50 BTry & 225 \\
\hline $\mathrm{Y}$ & $\begin{array}{l}\text { Acute phase patient, São Paulo, Brazil } \\
\text { (Pereira da Silva \& Nussenzweig 1953) }\end{array}$ & 30 BTry & 185 \\
\hline Buriti & $\begin{array}{l}\text { T. infestans from R.G. Sul, Brazil } \\
\text { (Filardi \& Brener 1987) }\end{array}$ & $2 \times 10^{5}$ MTry & 245 \\
\hline VL-10 & $\begin{array}{c}\text { Chronic chagasic patient from Minas Gerais, Brazil } \\
\text { (Schlemper Jr et al. 1983) }\end{array}$ & 50 BTry & 205 \\
\hline Generoso & $\begin{array}{c}\text { Acute phase patient from Minas Gerais, Brazil } \\
\text { (Filardi \& Brener 1987) }\end{array}$ & $2 \times 10^{5}$ MTry & 218 \\
\hline SC-28 & $\begin{array}{c}\text { Isolated from a marmoset, Santa Catarina, Brazil } \\
\text { (Steindel 1993) }\end{array}$ & $2 \times 10^{5}$ MTry & 225 \\
\hline $\mathrm{J}$ & $\begin{array}{l}\text { Acute phase patient from Minas Gerais, Brazil } \\
\text { (Filardi \& Brener 1987) }\end{array}$ & 50 BTry & 218 \\
\hline Colombiana & $\begin{array}{l}\text { Patient from Colombia } \\
\text { (Federici et al 1964) }\end{array}$ & 50 BTry & 256 \\
\hline
\end{tabular}

BTry: blood forms; MTry: culture metacyclic trypomastigotes

immunosuppressed and control mice was daily determined according to Brener (1961), starting in the second week of treatment and pursue until the animals death.

Cy administration - Cy (Pravaz Division, Abbott Laboratories) was diluted in saline and injected weekly with doses of $200 \mathrm{mg} / \mathrm{kg}$. Treatment was extended for four weeks. For the experiments in which normal mice were immunosuppressed, single doses of $50 \mathrm{mg} / \mathrm{kg}$ of Cy was given two days before inoculation, followed by three weekly doses post infection. For this experiment groups of 10 female albino Swiss mice, 18$20 \mathrm{~g}$ were inoculated with $10^{4}$ Btry from CL and VL-10 strains by intraperitoneal route.

\section{RESULTS}

The percentage of reactivation of the Cy treated mice and the number of parasites at the peak of parasitemia compared with the control values were used as criteria for considering the infection recrudescence. Fig. 1 shows the percentages of reactivation in the groups of chronically infected mice inoculated with different $T$. cruzi strains immunosuppressed by $\mathrm{Cy}$. The infection recrudescence occurred in a range of $90.3 \%$ to $10.7 \%$ according to the strain used. Table II shows the numbers of blood forms in the peak of parasitemia in mice treated with Cy. Although the standard deviation in the outbred mice is rather high, the differences between mice treated with $\mathrm{Cy}$ and the untreated animals are highly significant and corresponds to Fig.1. Figs 2A-D show patterns of parasitemia curves in immunosuppressed and untreated mice groups. They show that there is no correlation between the subpatent or residual lev- els of parasitemia from the untreated animals and the parasitemia of the immunosuppressed mice. Mice inoculated with Buriti and J strains (Figs 2A, B) which show low numbers of circulating parasites by fresh blood examination display, when submitted to $\mathrm{Cy}$ treatment, peaks of parasitemia of, respectively, 80,000 and 3,000 BTry/5 $\mu$ l. On the other hand, the groups of mice inoculated with the VL-10 and CL strains (Figs 2C, D) which induce steady subpatent parasitemia present, when immunosuppressed in the same conditions, peaks of parasitemia, of respectively 400 and 30,000 BTry $/ 5 \mu 1$.

As control we also investigated whether the different levels of parasitemia induced by $\mathrm{Cy}$ in the chronically infected mice were due to intrinsic differences in the replication rate of BTry from the different strains. Thus, naive mice treated with Cy according to Materials and Methods had been inoculated with $10^{4}$ BTry from VL-10 and CL strains. Fig. 3 shows that both strains yielded similar curves of parasitemia characterized by ex-



Fig. 1: percentages of mice with reactivated infection induced by cyclophosphamide in groups of mice chronically infected with different Trypanosoma cruzi strains. 


\section{TABLE II}

Parasitemia in chronically infected mice treated with cyclophosphamide (Cy) and controls

\begin{tabular}{cccc}
\hline Buriti & CL & J & Colombiana \\
\hline $\begin{array}{c}55.360 \pm 54.064^{a} \\
84 \pm 183^{b}\end{array}$ & $30.289 \pm 26.919$ & $8.158 \pm 4.403$ & $106 \pm 212$ \\
\hline Generoso & 0 & SC- 28 & $2.157 \pm 2.620$ \\
$384 \pm 362$ & $371 \pm 253$ & $156 \pm 380$ & Y \\
0 & $39 \pm 54$ & 0 & $46 \pm 66$ \\
\hline
\end{tabular}

$a$ : mean number of trypomastigotes in the peak of parasitemia in mice submitted to Cy treatment. $b$ : mean number of trypomastigotes in the peak of parasitemia in mice not submitted to Cy treatment.
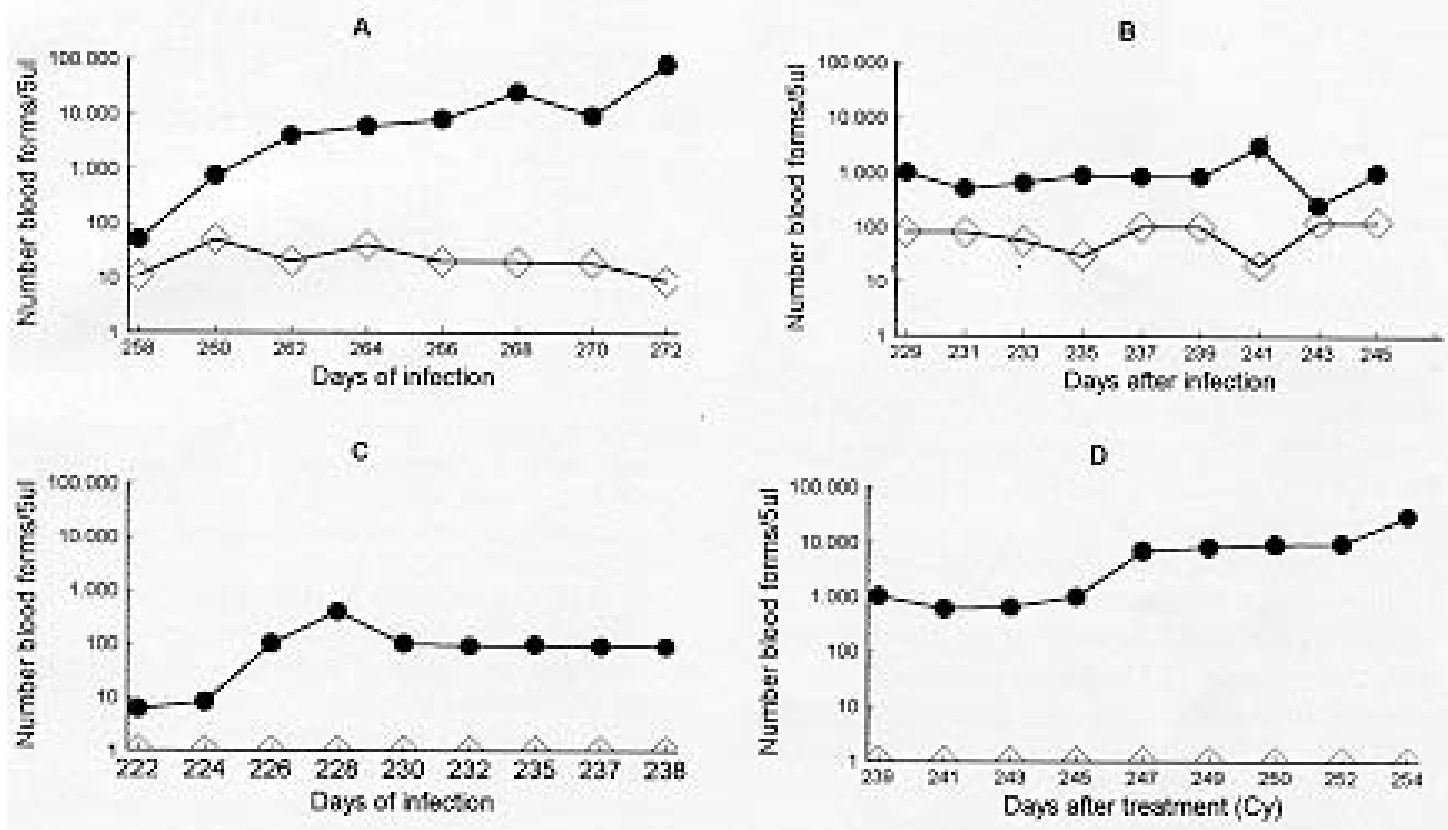

\section{Treated Untreated}

Fig. 2: curves of parasitemia in mice chronically infected with different Trypanosoma cruzi strains and immunosuppressed by cyclophosphamide as well as sham-treated controls. Strains: A: Buriti; B: J; C: VL-10; D: CL.

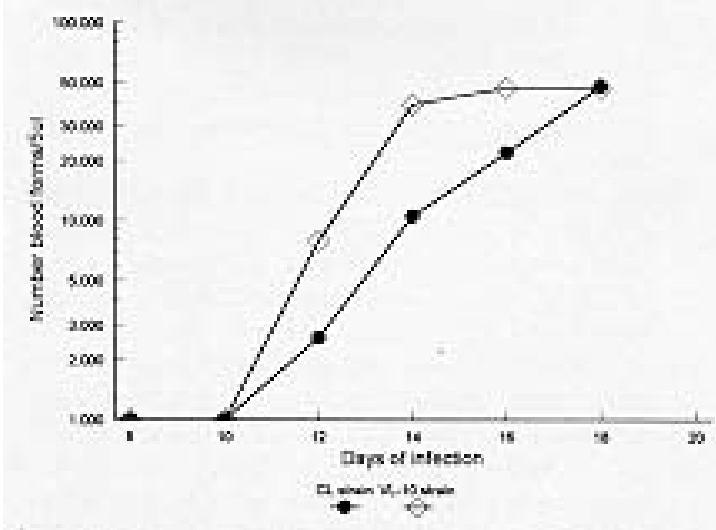

Fig. 3: curves of parasitemia of normal mice immunosuppressed by cyclophosphamide and inoculated with $10^{4}$ BTry of VL-10 and CL Trypanosoma cruzi strains. tremely high numbers of BTry, strongly suggesting that the differences in the percentages of recrudescence on the groups of the immunosuppressed mice do not depend on the replication rate of the BTry.

\section{DISCUSSION}

Recrudescence of the chronic chagasic patients is caused by various factors that interfere with the steady immune response mounted by T. cruzi. They are in general immunosuppressive cytotoxic drugs or concurrent infections of T. cruzi and HIV involving a decline of CD4 cells. Due to the difficulties to mimic all situations that induce immunosuppression we decided to use in our experiments $\mathrm{Cy}$, a suppressor of B lymphocyte function (Cupps et al. 1982) that demonstrated to reactivate T. cruzi in- 
fections (Brener \& Chiari 1971). The data herein confirm that an immunosuppressor factor that affects humoral response induces new outbreaks of acute Chagas disease in chronically infected mice, and also shows that $T$. cruzi strains react differently to the immunosuppressive effect. Krettli and Brener (1976) demonstrated that T. cruzi Y strain blood trypomastigotes incubated with homologous and heterologous specific anti-serum had their infectivity decreased whereas CL strain trypomastigotes remained unchanged with no decline of the infectivity. More evidences of the differences of $T$. cruzi strains vis a vis the specific acquired immunity was reported by Krettli (1977) who infected with Plasmodium berghei mice chronically infected with $\mathrm{Y}$ and CL T. cruzi strains and has shown that a strong immunosuppressive effect and recrudescence occurred in the CL-infected animals whereas the immune response against $\mathrm{Y}$ strain remained unchanged. The immunodeficiency observed in the rodents has been attributed to the depletion of $\mathrm{B}$ cells that occur in this malaria model (Krettli \& Nussenzweig 1974). These experiments performed with the "polar strains" Y and CL described by Brener (1977) have been now extended to a higher number of $T$. cruzi populations investigated under standardized conditions.

The variability in the percentage of mice reactivation is not induced by the inoculation of different development $T$. cruzi stages, namely, blood forms or metacyclic trypomastigotes from LIT culture. Buriti and Generoso strains, inoculated with $2 \times 10^{5}$ metacyclic trypomastigotes yielded in the LIT medium displayed, respectively, $90.3 \%$ and $12.9 \%$ of immunosuppressed mice, whereas in groups of mice inoculated with 50 bloodstream trypomastigotes of CL and VL-10 strains the percentages of reactivated mice were, respectivelly, $77.4 \%$ and $12.9 \%$. Moreover, no correlation could be established between the multiplication rate of blood forms from different strains and the results observed in the immunosuppressed chronically infected mice.

Taken together the data herein shown strongly suggest that this parasitism variability depends on intrinsic characteristics of the different $T$. cruzi strains. It has not yet been determined if this also occurs in immunodeficient chronic chagasic patients. Joint clinical and experimental investigations are worth to be carried out considering the increasing occurrence of $T$. cruzi recrudescence in human disease.

\section{REFERENCES}

Barousse AP, Costa JA, Eposto M, Laplume H, Segura EL 1980. Enfermedad de Chagas e inmunosupresión. Medicina 40: 17-26.

Brener Z 1961. Atividade terapêutica do 5-nitro-2- furaldeido-semicarbazona (nitrofurazona) em esquemas de duração prolongada na infecção experimental do camundongo pelo Trypanosoma cruzi. Rev Inst Med Trop São Paulo 3: 43-49.

Brener Z 1977. Intraspecific variations in Trypanosoma cruzi two types of parasite populations presenting distinct characteristics, p. 11-21. In Pan American Health Organization, Scientific Publication, no. 347.

Brener Z, Chiari E 1963. Variações morfológicas observadas em diferentes amostras de Trypanosoma cruzi. Rev Inst Med Trop São Paulo 5: 220-224.

Brener Z, Chiari E 1971. The effects of some immunosuppressive agents in experimental chronic Chagas disease. Trans R Soc Trop Med Hyg 65: 629-636.

Cupps TR, Lynn CE, Fauci AS 1982. Suppression of human B lymphocyte function by cyclophosphamide. J Immunol 128: 2453-2457.

Federici EE, Abelman WH, Neva FA 1964. Chronic and progressive myocarditis and myositis in $\mathrm{C} 3 \mathrm{H}$ mice infected with Trypanosoma cruzi. Am J Trop Med Hyg 13: 272-280.

Filardi LS, Brener Z 1987. Susceptibility and natural resistance of Trypanosoma cruzi strains to drugs used clinically in Chagas disease. Trans $R$ Soc Trop Med Hyg 81: 755-759.

Krettli AU 1977. Exacerbation of experimental Trypanosoma cruzi infection in mice by concomitant malaria. J Immunol 24: 514-518.

Krettli AU, Brener Z 1976. Protective effects of specific antibodies in Trypanosoma cruzi infections. $J$ Immunol 116: 755-760.

Krettli AU, Brener Z 1982. Resistance against Trypanosoma cruzi associated to anti-living trypomastigote antibodies. J Immunol 128: 2009-2012.

Krettli AU, Nussenzweig RS 1974. Depletion of T and B lymphocytes during malaria infections. Cel Immunol 13: 440-446.

Lopez Blanco OA, Cavalli NH, Jasovich A, Gotlieb D, Gonzalez-Cappa SM 1992. Chagas' disease and kidney transplantation. Follow up of nine patients for 11 years. Transplant Proc 24: 3089-3090.

Pereira da Silva LH, Nussenzweig V 1953. Sobre uma cepa de Trypanosoma cruzi altamente virulenta para o camundongo branco. Folia Clin Biol 20: 191-208.

Rocha A, Meneses ACO, Silva AM, Ferreira MS, Nishioka SA, Burgarelli MKN, Almeida E, Turcato Jr G, Metze K, Lopes ER 1994. Pathology of patients with Chagas' disease and acquired immunodeficiency syndrome. Am J Trop Med Hyg 50: 261 268.

Schlemper Jr BR, Ávila CM, Coura JR, Brener Z 1983. Course of infection and histopathological lesions in mice infected with seventeen Trypanosoma cruzi strains isolated from chronic patients. Rev Soc Bras Med Trop 16: 23-30.

Steindel M 1993. Caracterização de cepas de Trypanosoma cruzi $e$ Trypanosoma rangeli isoladas de reservatórios e vetores silvestres naturalmente infectados de Santa Catarina. $\mathrm{PhD}$ Thesis, University of Minas Gerais, Belo Horizonte, MG, Brazil, 166 pp.

Stolf NAG, Higuchi ML, Bocchi E, Belloti G, Auler OC, Uip D, Amato Neto V, Pillegi F, Jatene AD 1987. Heart transplantation in patients with Chagas' disease cardiomyopathy. J Heart Transplant 6: 307-312. 